\title{
Albumin Metabolism in Patients with Whipple's Disease*
}

\author{
Leonard Laster,$\dagger$ Thomas A. Waldmann, L. Frederick Fenster, $\ddagger$ and \\ JoH N W. Singleton $\S$ \\ (From the Section on Gastroenterology, Metabolic Diseases Branch, National Institute of \\ Arthritis and Metabolic Diseases, and the Metabolism Service, National Cancer Institute, \\ National Institutes of Health, Bethesda, Md.)
}

When malabsorption develops during the course of Whipple's intestinal lipodystrophy, it is often accompanied by hypoalbuminemia. Among 53 case reports published between 1951 and 1964 for which values of the concentration of albumin in the serum were presented, there were 43 values below $3.5 \mathrm{~g}$ per $100 \mathrm{ml}$ (Figure 1).

A decrease in the concentration of albumin in the serum may be due to dilution or to a decrease in the size of the body's total exchangeable pool of albumin. A reduction in the albumin pool size may result from decreased synthesis, from increased catabolism or loss, or from both causes. To explore the factors responsible for the hypoalbuminemia of Whipple's disease, we studied the albumin metabolism of seven patients with this disorder. Albumin labeled with ${ }^{131} \mathrm{I}$ or with ${ }^{125} \mathrm{I}$ was used to measure the total exchangeable pool of albumin and the rates of albumin catabolism and synthesis. Albumin $-{ }^{51} \mathrm{Cr}$ was used to measure loss of albumin into the gastrointestinal tract. The patients were studied when their disease was in relapse and again when therapy had induced marked improvement. The data suggest that abnormal exudation of serum protein into the gastrointestinal tract is an important factor in causing the hypoalbuminemia of Whipple's disease, that treatment of the disease can reverse this exudative enteropathy relatively rapidly, and that impairment of al-

\footnotetext{
* Submitted for publication October 4, 1965 ; accepted December 29, 1965.

Presented in part at the Annual Meeting of the American Gastroenterological Association, New York, April 27, 1962, and published in abstract form (1).

† Address requests for reprints to Dr. Leonard Laster, Chief, Section on Gastroenterology, Clinical Center $8 \mathrm{~N}-240$, National Institutes of Health, Bethesda, Md. 20014.

$\ddagger$ Present address: King County Hospital, Seattle, Wash.

$\S$ Present address : Division of Gastroenterology, University of Colorado Medical Center, Denver, Colo.
}

bumin synthesis may be associated with the exudative enteropathy.

\section{Methods}

Clinical. Six of the seven patients were first seen at the Clinical Center of the National Institutes of Health when their Whipple's disease was in mild to severe relapse. E.W. was in remission when first seen and remained off therapy for 3 years, when her disease again relapsed. In each patient the diagnosis of Whipple's disease in relapse was established by the demonstration in the lamina propria of the small intestinal mucosa of characteristic macrophages containing material that reacted with the periodic acid-Schiff stain. Electron microscopy revealed bacillary bodies (2) that disappeared from the intestinal mucosa soon after the onset of remission. Tests of intestinal absorptive functions gave abnormal results (Table I), but tests of hepatic and renal functions did not. A.W. was treated with antibiotics only; the others were treated with antibiotics and adrenocorticosteroids. All seven developed remissions. Detailed descriptions of the clinical and pathological features of these patients will appear elsewhere.

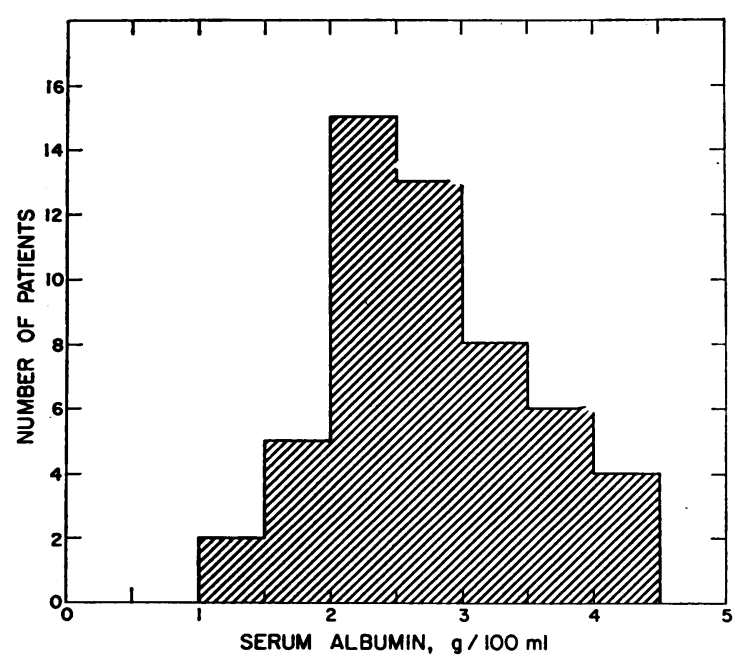

Fig. 1. VAlues for the concentration OF SERUM ALBUMIN REPORTED FOR 53 PATIENTS WITH WhIPPLE'S DISEASE. 


\begin{tabular}{|c|c|c|c|c|c|c|}
\hline \multirow{2}{*}{$\begin{array}{l}\text { Subject, age,* sex* } \\
\text { State of disease }\end{array}$} & \multicolumn{2}{|c|}{ S.J., 53, M } & \multicolumn{2}{|c|}{ E.L., 61, M } & \multicolumn{2}{|c|}{ F.R., 53, M } \\
\hline & Relapse & Remission & Relapse & Remission & Relapse & Remission \\
\hline \multicolumn{7}{|l|}{$\begin{array}{l}\text { Serum proteins, } \\
\mathrm{g} / 100 \mathrm{ml}\end{array}$} \\
\hline $\begin{array}{c}\text { Albumin } \dagger \\
\alpha_{1} \text {-Globulin } \\
\alpha_{2} \text {-Globulin } \\
\beta \text {-Globulin } \\
\gamma \text {-Globulin }\end{array}$ & 2.9 & $\begin{array}{l}4.0 \\
0.2 \\
0.3 \\
0.5 \\
0.9\end{array}$ & 2.0 & $\begin{array}{l}3.7 \\
0.3 \\
0.6 \\
0.7 \\
0.8\end{array}$ & 1.2 & 3.4 \\
\hline $\begin{array}{l}\text { Fat absorbed/day, } \\
\text { \% of intake }\end{array}$ & $85-95$ & $95+$ & $55-80$ & $95+$ & $50-80$ & 95 \\
\hline $\begin{array}{l}\text { Serum carotenoids, } \\
\quad \mu g / 100 \mathrm{ml}\end{array}$ & 43 & 140 & 20 & 160 & 15 & 200 \\
\hline $\begin{array}{l}\text { Serum cholesterol, } \\
\quad m g / 100 \mathrm{ml}\end{array}$ & 95 & 190 & 100 & 230 & 75 & 180 \\
\hline $\begin{array}{l}\text { D-Xylose tolerance test, } \\
\text { g/5-hour urine }\end{array}$ & 4.3 & 6.1 & 3.8 & 7.0 & & 6.2 \\
\hline $\begin{array}{l}\text { Lymphocytes in blood, } \\
\text { cells } / \mathrm{mm}^{3}\end{array}$ & 810 & 1,900 & 1,120 & 3,100 & 1,744 & 3,025 \\
\hline
\end{tabular}

* Age in years when first admitted; $M$, male, F, female.

+ Values for serum albumin concentration given together with those for globulins were determined by paper electrophoresis rather than the method of Rutstein, Ingenito, and Reynolds (3). Values for serum albumin concentration given in this Table are representative of those obtained during relapses and remissions, but may differ somewhat from those in Tables II and III because the latter were determined during the study periods pertinent to those Tables.

The subjects for the control studies of the metabolism of albumin labeled with ${ }^{121} \mathrm{I}$ or with ${ }^{120} \mathrm{I}$ were normal volunteers ranging in age from 21 to 55 years; the subjects for the control studies of albumin- ${ }^{51} \mathrm{Cr}$ metabolism included normal volunteers and patients with diseases not affecting the gastrointestinal tract. Each subject for a control study had a normal concentration of albumin in the serum.

The concentration of albumin in serum was determined by a modification of the method of Rutstein and co-workers (3). The partition of serum proteins was measured by paper electrophoresis, and the concentration of total protein was determined by a biuret method (4).

Determination of gastrointestinal tract permeability to albumin (5). A solution containing $30 \mu \mathrm{c}$ of albumin${ }^{*} \mathrm{Cr}$ was injected intravenously from a calibrated syringe. The stools passed during the next 4 days were collected, pooled in a 1-gallon stainless steel can, and stored in a refrigerator. Each collection was adjusted to a standard weight by the addition of water, homogenized with silica gravel by agitation on a shaker, assayed for radioactivity with a gamma ray spectrometer, and compared to an appropriate standard. The results were expressed as a percentage of the administered radioactivity excreted in the stools during the 4-day collection period.

Kinetics of albumin metabolism. Albumin 1 was labeled with ${ }^{121} \mathrm{I}$ or ${ }^{125} \mathrm{I}$ by the iodine monochloride method of MacFarlane (6). A measured volume of a solution of

1 Cohn Fraction V, Cutter Laboratories, Berkeley, Calif. labeled albumin containing approximately $100 \mu \mathrm{c}$ was injected intravenously for each study. Uptake of ${ }^{181} \mathrm{I}$ or ${ }^{125} \mathrm{I}$ by the thyroid gland was inhibited by administration of $0.5 \mathrm{ml}$ of Lugol's solution every 8 hours throughout a study. Blood samples were taken without stasis 15 and 30 minutes after the albumin injection and at least three times a week for the next 3 weeks. Twenty-four-hour collections of all the urine and stools passed during each study were obtained. The radioactivity of each collection was measured with a well-type scintillation counter and compared to an appropriate standard.

The concentration of albumin in the serum was determined three to four times during a study, and the mean value was used for the calculations. There was no significant change in the concentration of albumin in the serum during any of the studies.

The data were analyzed, with slight modifications, according to the method of Berson, Yalow, Schreiber, and Post (7). Values were determined for total circulating albumin, total exchangeable albumin pool, albumin turnover, and the fraction of circulating albumin degraded per day. This fraction represents all the albumin degraded in the body including that lost into the lumen of the gastrointestinal tract and catabolized there. Because of the relative constancy of the concentration of albumin in the serum during each study, the patients were regarded as being in a steady state, and the value for albumin turnover was considered equal to the value for the rate of albumin synthesis. Detailed descriptions of the calculations have been presented previously (8). 
TABLE I

of the patients

\begin{tabular}{|c|c|c|c|c|c|c|c|c|}
\hline \multicolumn{2}{|c|}{ J.S., 25, M } & \multicolumn{2}{|c|}{ R.T., 48, M } & \multicolumn{2}{|c|}{ A.W., 42, M } & \multicolumn{3}{|c|}{ E.W., 38, F } \\
\hline Relapse & Remission & Relapse & Remission & Relapse & Remission & Remission & Relapse & Remission \\
\hline $\begin{array}{l}2.1 \\
0.5 \\
0.7 \\
0.9 \\
0.8\end{array}$ & $\begin{array}{l}4.4 \\
0.2 \\
0.6 \\
0.7 \\
0.8\end{array}$ & $\begin{array}{l}1.3 \\
0.4 \\
0.9 \\
0.6 \\
0.5\end{array}$ & $\begin{array}{l}3.5 \\
0.3 \\
0.5 \\
0.8 \\
1.1\end{array}$ & $\begin{array}{l}2.5 \\
0.3 \\
0.5 \\
0.7 \\
0.6\end{array}$ & $\begin{array}{l}3.6 \\
0.4 \\
1.0 \\
1.0 \\
1.2\end{array}$ & $\begin{array}{l}4.5 \\
0.2 \\
0.6 \\
0.7 \\
1.2\end{array}$ & $\begin{array}{l}1.3 \\
0.4 \\
0.7 \\
0.9 \\
2.0\end{array}$ & $\begin{array}{l}2.8 \\
0.3 \\
0.6 \\
1.1 \\
0.9\end{array}$ \\
\hline $25-65$ & $95+$ & $40-75$ & $95+$ & $45-75$ & $95+$ & $95+$ & $95+$ & $95+$ \\
\hline 10 & 120 & 13 & 250 & 15 & 140 & 200 & 45 & 175 \\
\hline 80 & 173 & 120 & 195 & 93 & 200 & 230 & 85 & 230 \\
\hline 2.4 & 6.1 & 3.8 & 7.2 & 2.1 & 5.7 & 6.5 & 5.3 & 7.7 \\
\hline 365 & 1,010 & 560 & 1,800 & 550 & 1,440 & 1,160 & 380 & 1,400 \\
\hline
\end{tabular}

\section{Results}

Whipple's disease in relapse. At some time during relapse each patient was tested for fecal excretion of radioactivity after intravenous injection of albumin- ${ }^{51} \mathrm{Cr}$. The results are presented in Table II together with values for the concentration of albumin in the serum at the time of study. For each of the patients but S.J. the albumin concentration was less than $2.5 \mathrm{~g}$ per $100 \mathrm{ml}$ during relapse. In each patient there was an abnormally high fecal excretion of ${ }^{51} \mathrm{Cr}$, indicating that excessive loss of protein into the gastrointestinal tract, or proteinlosing gastroenteropathy, was a consistent finding in these patients when their disease was in relapse.

The turnover of intravenously injected albumin labeled with ${ }^{131} \mathrm{I}$ or ${ }^{125} \mathrm{I}$ was studied in four of the seven patients when their disease was in relapse (Table III). Each patient's hypoalbuminemia was associated with reductions in the total circulating albumin and the total exchangeable albumin pool. These findings exclude the possibilities that the hypoalbuminemia was attributable to increased plasma volume or to abnormal distribution of albumin among body compartments. The per cent of the intravascular albumin catabolized per day by each of the four patients exceeded the upper limit of the control range, and in the three instances where it was determined, the fecal excretion of labeled iodine was greater than normal. These observations indicate that there was excessive loss of albumin into the gastrointestinal tract and thus confirm the results of the studies with albumin- ${ }^{51} \mathrm{Cr}$. The estimates of the rate of albumin turnover (synthesis) were within the control range for J.S. and A.W. even when their disease was in relapse, whereas E.L.'s synthetic rate was slightly below the lower limit of the control range, and E.W.'s was definitely below the lower limit when these patients were in relapse. Because the concentration of albumin in the serum of E.L. may have been declining during the study period, the true rate of albumin synthesis may have been even lower than the estimated value presented in Table III.

Response to treatment. Each patient improved after treatment with either antibiotics and corticosteroids or with antibiotics alone. Improvement was manifested by return of a feeling of well-being, weight gain, subsidence of diarrhea and malabsorption, disappearance of bacillary bodies from the 
TABLE II

Studies of gastrointestinal tract protein loss (albumin- ${ }^{51} \mathrm{Cr}$ test) in patients with Whipple's disease in relapse and in remission

\begin{tabular}{|c|c|c|c|c|c|c|c|}
\hline \multirow[b]{3}{*}{ Subject } & \multirow{2}{*}{\multicolumn{3}{|c|}{ Relapse }} & \multirow[b]{3}{*}{$\begin{array}{l}\text { Date definitive } \\
\text { therapy started }\end{array}$} & \multicolumn{3}{|c|}{ Remission } \\
\hline & & & & & \multirow[b]{2}{*}{ Date } & \multirow[b]{2}{*}{$\begin{array}{l}\text { Serum } \\
\text { albumin }\end{array}$} & \multirow{2}{*}{$\begin{array}{c}\text { Albumin- } \\
\text { s1Cr, } \\
\text { 4-day } \\
\text { fecal } \\
\text { excretion }\end{array}$} \\
\hline & Date & $\begin{array}{c}\text { Serum } \\
\text { albumin }\end{array}$ & $\begin{array}{l}\text { Albumin-51Cr, } \\
\text { 4-day fecal, } \\
\text { excretion }\end{array}$ & & & & \\
\hline Controls, 75 & & $\begin{array}{l}g / 100 \mathrm{ml} \\
3.5-5.5\end{array}$ & $\begin{array}{l}\% \text { of dose } \\
0.1-0.7\end{array}$ & & & $\mathrm{~g} / 100 \mathrm{ml}$ & $\%$ of dose \\
\hline R.T. & $11 / 16 / 61$ & 0.7 & 22.1 & $11 / 20 / 61$ & $\begin{array}{r}12 / 2 / 61 \\
8 / 29 / 62 \\
6 / 19 / 64 \\
12 / 28 / 64\end{array}$ & $\begin{array}{l}1.7 \\
2.2 \\
2.2 \\
2.4\end{array}$ & $\begin{array}{l}2.4 \\
0.9 \\
3.6 \\
1.9\end{array}$ \\
\hline F.R. & $11 / 27 / 61$ & 1.8 & 8.2 & $11 / 29 / 61$ & $\begin{array}{r}12 / 21 / 61 \\
2 / 27 / 62\end{array}$ & $\begin{array}{l}2.3 \\
3.4\end{array}$ & $\begin{array}{l}1.9 \\
0.6\end{array}$ \\
\hline E.L. & $2 / 27 / 62$ & 2.4 & 5.2 & $3 / 20 / 62$ & $\begin{array}{r}4 / 5 / 62 \\
10 / 28 / 63\end{array}$ & $\begin{array}{l}2.8 \\
3.8\end{array}$ & $\begin{array}{l}0.2 \\
0.2\end{array}$ \\
\hline J.S. & $4 / 19 / 61$ & 1.6 & 4.2 & $5 / 23 / 61$ & $7 / 24 / 62$ & 3.5 & 0.6 \\
\hline E.W. & $4 / 30 / 65$ & 1.2 & 4.1 & $\begin{array}{l}9 / 62 \text { (first } \\
\text { course) }\end{array}$ & $10 / 4 / 63$ & 3.4 & 0.2 \\
\hline A.W. & $9 / 10 / 62$ & 2.0 & 3.5 & $9 / 19 / 62$ & $11 / 20 / 62$ & 2.7 & 0.3 \\
\hline S.J. & $11 / 8 / 61$ & 3.2 & 1.3 & & & & \\
\hline
\end{tabular}

intestinal mucosa, and decrease in the number of periodic acid-Schiff-positive macrophages in the lamina propria of the intestinal mucosa. With the onset of each remission there was a rise in the concentration of albumin in the patient's serum. The time course of the reversal of the hypoalbuminemia of two representative patients is shown in Figure 2.

TABLE III

Metabolism of iodinated human serum albumin by patients with Whipple's disease in relapse and in remission

\begin{tabular}{|c|c|c|c|c|c|c|}
\hline Subject & $\begin{array}{c}\text { Serum } \\
\text { albumin }\end{array}$ & $\begin{array}{l}\text { Total } \\
\text { circulating } \\
\text { albumin }\end{array}$ & $\begin{array}{l}\text { Total } \\
\text { exchangeable } \\
\text { albumin pool }\end{array}$ & $\begin{array}{c}\text { Fraction of } \\
\text { circulating } \\
\text { albumin } \\
\text { degraded } \\
\text { per day }\end{array}$ & $\underset{\text { turnover }}{\text { Albumin }}$ & $\begin{array}{l}\text { 121I in } \\
\text { stool per } \\
\text { day as \% } \\
\text { of bodyt } \\
\text { albumin--13i } \\
\text { content }\end{array}$ \\
\hline Controls, 12 & $g / 100 \mathrm{ml}$ & $\begin{array}{l}\mathrm{g} / \mathrm{kg} \\
1.5-2.0\end{array}$ & $\begin{array}{l}\mathrm{g} / \mathrm{kg} \\
3.6-4.6\end{array}$ & $0.09-0.13$ & $\begin{array}{l}\mathrm{g} / \mathrm{kg} / \mathrm{day} \\
0.16-0.20\end{array}$ & $0-0.4$ \\
\hline \multicolumn{7}{|l|}{ J.S. } \\
\hline $\begin{array}{l}\text { Before therapy } \\
\text { After } 73 \text { days of therapy }\end{array}$ & $\begin{array}{l}1.9 \\
3.2\end{array}$ & $\begin{array}{l}0.92 \\
1.44\end{array}$ & $\begin{array}{l}2.1 \\
4.0\end{array}$ & $\begin{array}{l}0.20 \\
0.13\end{array}$ & $\begin{array}{l}0.18 \\
0.19\end{array}$ & $\begin{array}{l}0.86 \\
0.04\end{array}$ \\
\hline \multicolumn{7}{|l|}{ A.w. } \\
\hline $\begin{array}{l}\text { Before therapy } \\
\text { After } 125 \text { days of therapy }\end{array}$ & $\begin{array}{l}2.0 \\
3.2\end{array}$ & $\begin{array}{l}0.88 \\
1.37\end{array}$ & $\begin{array}{l}2.0 \\
3.7\end{array}$ & $\begin{array}{l}0.23 \\
0.16\end{array}$ & $\begin{array}{l}0.20 \\
0.21\end{array}$ & $\begin{array}{l}0.50 \\
0.04\end{array}$ \\
\hline \multicolumn{7}{|l|}{ E.L. } \\
\hline Before therapy & 1.9 & 0.77 & 2.2 & 0.20 & 0.15 & 0.13 \\
\hline $\begin{array}{l}\text { E.W. } \\
\text { Before second course of } \\
\text { therapy }\end{array}$ & 1.2 & 0.56 & 1.5 & 0.22 & 0.13 & \\
\hline \multicolumn{7}{|l|}{ R.T. } \\
\hline $\begin{array}{l}\text { During clinical remission } \\
\text { June } 1964 \\
\text { December } 1964\end{array}$ & $\begin{array}{l}2.2 \\
2.4\end{array}$ & $\begin{array}{l}0.77 \\
0.77\end{array}$ & $\begin{array}{l}1.8 \\
2.1\end{array}$ & $\begin{array}{l}0.14 \\
0.13\end{array}$ & $\begin{array}{l}0.11 \\
0.10\end{array}$ & \\
\hline
\end{tabular}




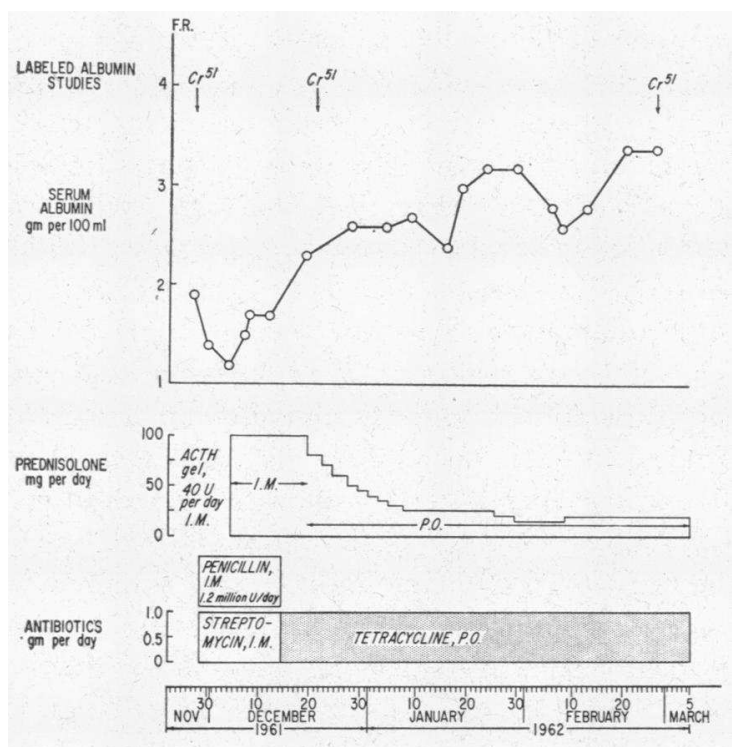

fore treatment, lost only $2.4 \%$ by the twelfth day of therapy. A.W., who was treated with antibiotics only, showed a slower response of his serum albumin (Figure 2), but his exudative enteropathy was reversed, and by the sixty-fifth day of treatment the result of his albumin $-{ }^{51} \mathrm{Cr}$ test fell within the control range.

Repeat studies of albumin- ${ }^{131}$ I metabolism were carried out on J.S. and A.W. when they were in remission (Table III). J.S. was studied 73 days after the start of therapy. The concentration of albumin in his serum had increased to $3.2 \mathrm{~g}$ per $100 \mathrm{ml}$, his total circulating albumin had increased almost to normal, and his total exchangeable albumin pool was within the control range. The mechanism of this improvement is indicated by the decrease in the rate of albumin catabolism from an abnormally high value to a normal one (Figure 3 ) and by the fall in the per cent of ${ }^{131} \mathrm{I}$ excreted

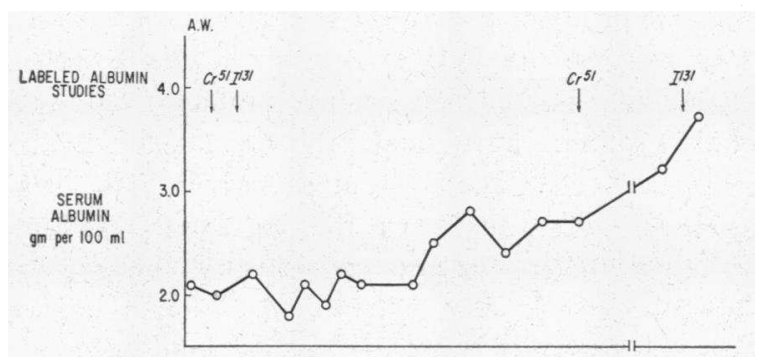
in the feces to a normal value (Table III). The rate of albumin synthesis remained within the control range. Similar results were obtained when A.W. was studied 125 days after the onset of therapy. Thus, these determinations of albumin- ${ }^{131} I$ turnover, like the investigations of fecal excretion

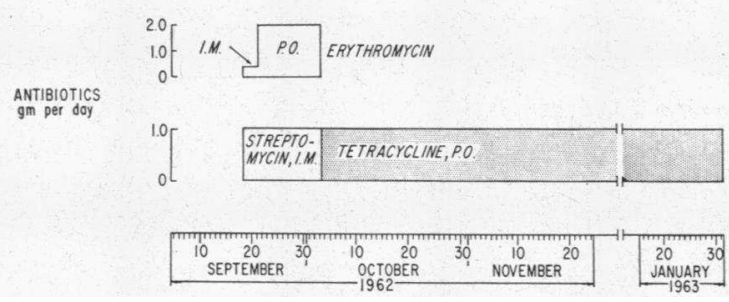

Fig. 2. TEMPORAL RELATIONSHIPS AMONG THERAPY, CONCENTRATION OF ALBUMIN IN THE SERUM, AND STUDIES OF METABOLISM OF LABELED HUMAN SERUM ALBUMIN. Representative data for two patients, one treated with antibiotics and adrenocorticosteroids (F.R.) and the other with antibiotics only (A.W.) $\mathrm{PO}=$ orally.

The albumin- ${ }^{51} \mathrm{Cr}$ test was repeated serially, and in each patient the rate of fecal loss of ${ }^{51} \mathrm{Cr}$ returned to or toward normal (Table II). The rapidity of the reversal of the exudative enteropathy is illustrated by the case of E.L., whose values for the albumin $-{ }^{51} \mathrm{Cr}$ test went from the abnormally high $5.2 \%$ before treatment to $0.2 \%$ (within the control range) by the sixteenth day of therapy. R.T., who lost $22 \%$ of injected albumin- ${ }^{51} \mathrm{Cr}$ be-

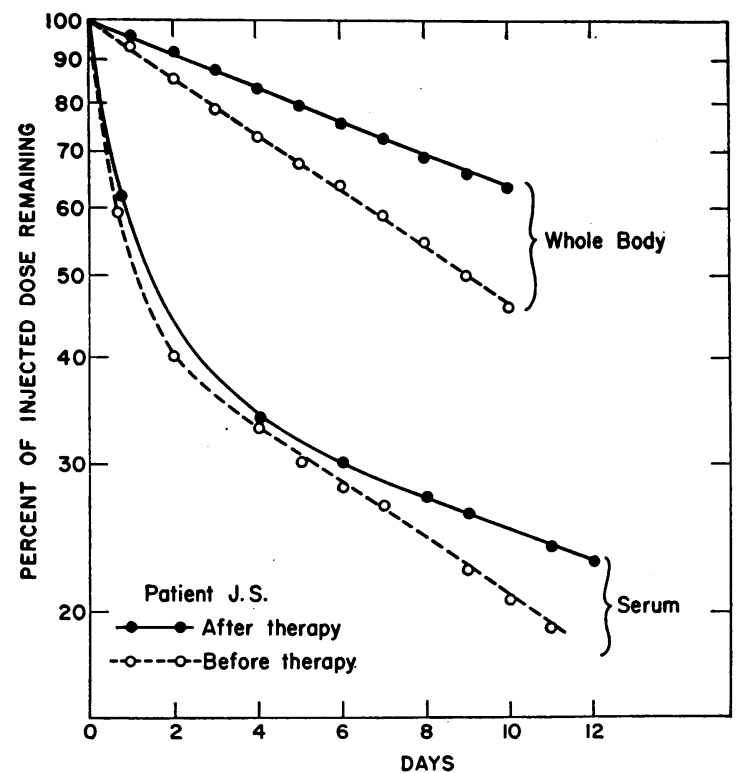

Fig. 3. TURNover OF ALBUMIN- ${ }^{191}$ I IN J.S. IN RELAPSE AND IN REMIssion. The albumin survival half-time was 9 days (abnormally low) during relapse and 15.5 days (within control range) during remission. Similar graphic analyses were made for the other studies of the turnover of iodinated albumin. 


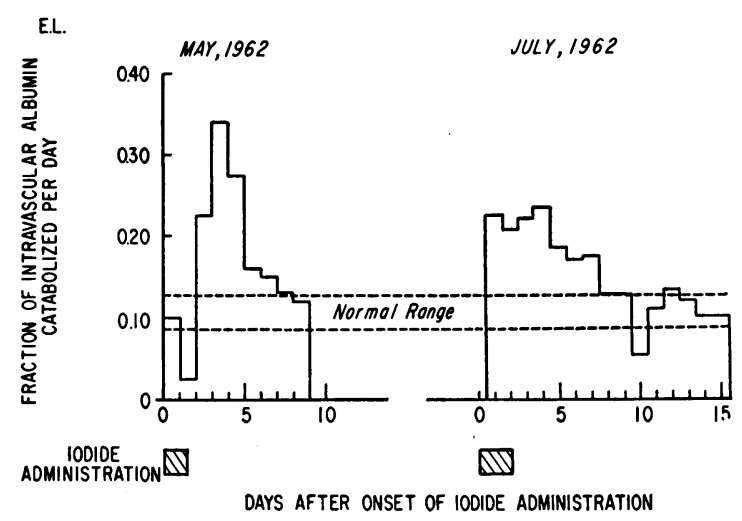

Fig. 4. Studies of the rate of albumin catabolism BY E.L. DURING TWO ACUTE EPISODES ATTRIBUTED TO REACTIONS TO IODIDE.

of albumin ${ }^{51} \mathrm{Cr}$, indicated that the exudative gastroenteropathy was reversed.

Recurrences of hypoalbuminemia. Once remissions had been induced, four patients were, and E.W., R.T., and E.L. were not, able consistently to maintain a concentration of albumin in the serum well above $3 \mathrm{~g}$ per $100 \mathrm{ml}$. As mentioned earlier, 3 years after E.W.'s disease had first been brought into remission and treatment discontinued, she developed a relapse and the concentration of albumin in her serum fell markedly. During that relapse laboratory studies revealed both excessive gastrointestinal protein loss and impaired synthesis of albumin (Tables II and III). With her second course of treatment, in 1965, the concentration of albumin in her serum rose again to normal values.

R.T.'s initial response to treatment was favorable. The concentration of albumin in his serum rose, and the results of albumin $-{ }^{51} \mathrm{Cr}$ tests returned toward normal (Table II). However, in May 1962, he again developed hypoalbuminemia that persisted for 3 years during which time we could find no evidence for a relapse of his Whipple's disease or for liver or kidney disease. Our studies indicated a recurrence of excessive enteric protein loss (Table II) and impairment of albumin synthesis (Table III). Early in 1965 the concentration of albumin in his serum rose to $3.5 \mathrm{~g}$ per 100 $\mathrm{ml}$, and it has remained at that level or higher ever since. This change may have accompanied cessation of prolonged treatment with tetracycline; this speculation is the only explanation we can give for the recurrence and persistence of the abnor- malities of albumin metabolism after the Whipple's disease had been brought into apparent remission.

E.L. experienced two episodes of acute exudative enteropathy after the onset of the remission of his disease. In May 1962, when the concentration of albumin in his serum was $3.6 \mathrm{~g}$ per $100 \mathrm{ml}$, we started a repeat study of the turnover of iodinated albumin, and within several hours he developed shock, oliguria, fever, massive diarrhea, and prostration, and the serum albumin concentration fell to $2.0 \mathrm{~g}$ per $100 \mathrm{ml}$. He was treated for the various diagnostic possibilities we considered, the study of albumin metabolism was discontinued, and he recovered fairly rapidly. Two months later a study of iodinated albumin metabolism was attempted again, and a similar but milder reaction took place. In each instance the preparation of labeled albumin had been given to other subjects without producing untoward reactions. Although sensitivity to human serum albumin could not be excluded, we regarded this as unlikely and concluded rather that he had probably reacted to the iodide in the Lugol's solution, which had been administered orally with the iodinated albumin. Whether the medication had affected the gut independently or whether it had reactivated the Whipple's disease could not be determined. Similar changes in albumin metabolism were noted during each reaction (Figure 4 ). There was a marked rise in the rate of catabolism of albumin to pathological levels, due presumably to sudden excessive loss of albumin into the gastrointestinal tract. As the reactions subsided, the rate of albumin catabolism fell to normal. We suggest that this sequence of events represents iatrogenic, druginduced, exudative gastroenteropathy and that it illustrates how rapidly the gastrointestinal tract can start and stop leaking abnormal amounts of serum protein.

\section{Discussion}

Hypoalbuminemia is a relatively common feature of Whipple's disease in relapse. Each of the seven patients in the present investigation exhibited this abnormality when his disease was active. The results of the albumin- ${ }^{51} \mathrm{Cr}$ tests and of the studies of the turnover of iodinated albumin indicated that in each patient excessive loss of serum protein into the gastrointestinal tract was a significant factor in the pathogenesis of the hypo- 
albuminemia. The rates at which four of the patients were synthesizing albumin when their disease was in obvious clinical relapse were determined (Table III). The synthetic rate was within the control range for J.S. and A.W., slightly suppressed for E.L., and significantly depressed for E.W. Patients with exudative enteropathy due to other causes have been shown to be capable of increasing the rate of albumin synthesis above the control range as a compensatory response to the stimulus of the hypoalbuminemia $(9,10)$. Therefore, even though the synthetic rates for J.S. and A.W. were within the control range, these findings indicate that they each had a relative impairment of the regulatory mechanism for albumin synthesis. Thus, a second factor in the hypoalbuminemia of Whipple's disease is absolute and relative impairment of albumin synthesis. The cause of this impairment could not be elucidated. No evidence of liver or renal dysfunction was obtained. Amino acid absorption was assessed by means of the $\alpha$-aminoisobutyric acid absorption test (11). The results indicated impaired absorption when E.L. was in relapse and a return to normal when he was in remission. However, when E.W. was in relapse and her albumin synthetic rate well below the control range, the result of her absorption test fell within control limits.

The exudative enteropathy of Whipple's disease responds quite rapidly to the therapeutic induction of a remission. The concentration of albumin in the serum of each patient rose rapidly toward normal after the initiation of appropriate treatment and was accompanied by a return of the results of the albumin ${ }^{51} \mathrm{Cr}$ test to or toward normal values. The inadvertent precipitation in E.L. of what we interpret in retrospect to have been exudative' gastroenteropathy secondary to reactions to Lugol's solution indicates that abnormal loss of protein into the gut can be induced and can stop with extreme rapidity, and suggests the possibility that reactions to other drugs may produce the same consequences. We could not determine from our observations whether E.L. would have developed the apparent drug sensitivity and experienced the acute pathological increase in gastrointestinal protein loss if he had not had Whipple's disease as a possible predisposing factor. Other instances of drug-induced exudative gastroenter- opathy should be sought and attention given to the problem of whether underlying disease of the gastrointestinal tract is a prerequisite condition.

In considerations of the pathophysiology of exudative gastroenteropathy it has been suggested that one of the possible causes is a disorder of the gastrointestinal lymphatics that leads to abnormal losses of lymph into the lumen of the gut. Dilated lymphatics in the mucosa of the small intestine have been demonstrated in patients with intestinal lymphangiectasia $(9,10,12)$ and with constrictive pericarditis $(13,14)$. Patients with these disorders and exudative gastroenteropathy have abnormally low numbers of circulating lymphocytes in the peripheral blood, an abnormality that has been attributed to the fact that lymph is rich not only in serum proteins but also in lymphocytes (15). Patients with exudative gastroenteropathy not associated with disorders of the intestinal lymphatics do not have lymphopenia. Abnormalities of the lymphatics of the small intestine are a major feature of Whipple's disease, and the peripheral lymph nodes are often involved in the disease. In the present series of patients two showed marked and one showed mild dilatation of the lymphatics of the intestinal mucosa. There was an absolute lymphopenia in six of the seven patients (Table I) when they were in relapse, and with the onset of remission each of the seven patients showed a rise in the lymphocyte count to almost twice pretreatment levels. These findings suggest that the lymphatic abnormalities of Whipple's disease may be involved in the pathogenesis of the exudative gastroenteropathy. It must be noted, however, that when the exudative gastroenteropathy of the two patients in the present study with markedly dilated mucosal lymphatics had subsided, there was either no change or an apparent increase in the dilatation of the mucosal lymphatics. Ulcerations of the gastrointestinal mucosa, which might possibly explain abnormal protein loss, are not a prominent feature of Whipple's disease. The other abnormalities that were seen in the intestinal mucosa of the patients in the present study such as the alterations of the lining epithelial cells may contribute to the abnormal protein loss. It is our impression, however, that the primary factor in the excessive protein loss is related to the disorder of the intestinal lymphatics. 


\section{Summary}

Hypoalbuminemia is common in patients with Whipple's disease in relapse. Seven patients with this disorder were studied for gastrointestinal protein loss by the use of albumin ${ }^{-51} \mathrm{Cr}$. The results show that exudative gastroenteropathy is a significant factor in causing the hypoalbuminemia.

In four of the patients the turnover of iodinated human serum albumin was determined; the results indicate that impaired synthesis of albumin, absolute or relative, also contributes to the hypoalbuminemia.

After induction of remissions of the Whipple's disease with appropriate therapy the exudative gastroenteropathy was rapidly reversed.

On two different occasions one of the patients in remission developed acute excessive gastrointestinal protein loss due apparently to reactions to the administration of Lugol's solution. The possibility that other drugs may induce exudative gastroenteropathy should be considered.

\section{Acknowledgments}

We are grateful to the following physicians for referring their patients to us for study: Dr. David S. Davis, Washington, D. C. (S.J.) ; Dr. Elmore R. McNeal, Youngstown, Ohio (E.L.); Dr. Robert J. Gallagher, Yeadon, Pa. (F.R.) ; Dr. Clarence R. Hartman, Washington, D. C. (J.S.) ; Dr. Thomas M. McMillan III, Mount Holly, N. J. (R.T.) ; Dr. Clarence W. Legerton, Jr., Charleston, S. C. (A.W.) ; and Dr. John T. Crowe, Cape Girardeau, Mo. (E.W.). Drs. Elliot Weser, James D. Finkelstein, and Robert K. Ockner, while serving as Clinical Associates of the Section on Gastroenterology, National Institute of Arthritis and Metabolic Diseases, contributed greatly to the care of the patients during the periods of prolonged study. Mrs. Minnie L. Woodson and Mr. William A. Edwards provided expert technical assistance.

\section{References}

1. Laster, L., T. A. Waldmann, L. F. Fenster, and J. W. Singleton. Reversible enteric protein loss in Whipple's disease (abstract). Gastroenterology 1962, 42, 762 .
2. Trier, J. S., P. C. Phelps, S. Eidelman, and C. E. Rubin. Whipple's disease: light and electron microscope correlation of jejunal mucosal histology with antibiotic treatment and clinical status. Gastroenterology $1965,48,684$.

3. Rutstein, D. D., E. F. Ingenito, and W. E. Reynolds. The determination of albumin in human blood plasma and serum. A method based on the interaction of albumin with an anionic dye-2-(4'hydroxy-benzeneazo) benzoic acid. J. clin. Invest. 1954, 33, 211.

4. Gornall, A. G., C. J. Bardawill, and M. M. David. Determination of serum proteins by means of the biuret reaction. J. biol. Chem. 1949, 177, 751.

5. Waldmann, T. A. Gastrointestinal protein loss demonstrated by ${ }^{51} \mathrm{Cr}$-labelled albumin. Lancet 1961 , 2, 121.

6. McFarlane, A. S. Efficient trace-labelling of proteins with iodine. Nature (Lond.) 1958, 182, 53.

7. Berson, S. A., R. S. Yalow, S. S. Schreiber, and J. Post. Tracer experiments with $\mathrm{I}^{131}$ labeled human serum albumin: distribution and degradation studies. J. clin. Invest. 1953, 32, 746.

8. Waldmann, T. A., and L. Laster. Abnormalities of albumin metabolism in patients with hypogammaglobulinemia. J. clin. Invest. 1964, 43, 1025.

9. Schwartz, M., and S. Jarnum. Protein-losing gastroenteropathy. Hypoproteinaemia due to gastrointestinal protein loss of varying aetiology, diagnosed by means of ${ }^{131} \mathrm{I}$-albumin. Danish med. Bull. 1961, 8, 1.

10. Waldmann, T. A., J. L. Steinfeld, T. F. Dutcher, J. D. Davidson, and R. S. Gordon, Jr. The role of the gastrointestinal system in "idiopathic hypoproteinemia.” Gastroenterology 1961, 41, 197.

11. Laster, L., and D. M. Matthews. Intestinal absorption and malabsorption of the amino acid analogue, alpha-aminoisobutyric acid in man (abstract). J. clin. Invest. 1963, 42, 948.

12. Holman, H., W. F. Nickel, Jr., and M. H. Sleisenger. Hypoproteinemia antedating intestinal lesions, and possibly due to excessive serum protein loss into the intestine. Amer. J. Med. 1959, 27, 963.

13. Petersen, V. P., and J. Hastrup. Protein-losing enteropathy in constrictive pericarditis. Acta med. scand. 1963, 173, 401.

14. Kaihara, S., H. Nishimura, T. Aoyagi, H. Kameda, and $\mathrm{H}$. Ueda. Protein-losing gastroenteropathy as cause of hypoproteinemia in constrictive pericarditis. Jap. Heart J. 1963, 4, 386.

15. Jarnum, S. Protein-losing Gastroenteropathy. Oxford, Blackwell, 1963. 